\title{
PLUTARCH, MORALIA 505C: SOME NOTES ON THE DISCOVERY OF THE PISONIAN CONSPIRACY
}

\begin{abstract}
Summary: Although it is primarily through Tacitus' narration of the event that we are able to reconstruct the Pisonian conspiracy, the particular details of the plot can be partially completed from other sources of information. In that regard, relatively little time has been devoted to Plutarch's account - found in his essay De garrulitate - of the discovery of the Pisonian plot. The account to some extent poses a problem, as it does not explicitly specify which conspiracy it refers to. In addition, the account is in the form of a moral essay; most importantly, it proffers a version of the events of AD 65 (when the plot was disclosed) that is totally different from that of Tacitus. Therefore, the purpose of this paper is at least partially to incorporate Plutarch's report into the whole, rather foggy portrayal of the Pisonian conspiracy, and simultaneously to point to the fact that Plutarch's report may not be an alternative to Tacitus' one, but rather a complement of it. The author strives to evaluate the various literary and historical elements of the report, as well as its possible sources, and following the knowledge obtained, to assess its informative value within the broader context of the entire conspiracy.
\end{abstract}

Key words: Pisonian conspiracy, Plutarch, De garrulitate, Tacitus, literary and historical elements

\section{INTRODUCTION}

Historians usually rely on Tacitus to reconstruct the story of the Pisonian conspiracy. ${ }^{1}$ However, while Tacitus' Annales is the main source for these events, it is certainly not the only one; this also applies to the discovery of the conspiracy. For instance, one passage addressing a conspiracy against Nero can be found in Plutarch's essay De garrulitate ("On Talkativeness"). However, the passage remains questionable, because Plutarch does not specify which insurrection he is referring to;

${ }^{1}$ See Griffin, M.: Nero. The End of a Dynasty. New York 1984, 167-168; FinI, M.: Nero. Zweitausend Jahre Verleumdung. München 1994, 184-188; WIEDEMANN, T.: Tiberius to Nero. In The Cambridge Ancient History. Ed. A. Bowman - E. ChAMPlin - A. LinTotT. Cambridge 1996, 252; ShOtTER, D.: Nero. London - New York 1997, 68-69; MALITZ, J.: Nero. Oxford 2005, 82; and others. 
multiple rebellions occurred during Nero's rule, ${ }^{2}$ and it is therefore not clear that Plutarch's comments are associated with the Pisonian conspiracy specifically. Despite this foundational uncertainty, we will consider the remark a reference to the Pisonian conspiracy, based on the following reasoning: in his essay, Plutarch illustrates his personal reflections and arguments using various historical examples, whose contexts seem to have been clear to Plutarch's contemporaries. Thus, when speaking of the conspiracy, he did not feel it necessary to specify which instance he was referring to - he assumed the readers would easily identify this information. According to Tacitus, the Pisonian conspiracy was the largest rebellion against Nero during the emperor's rule. After the plot was discovered, there were many interrogations and punishments, and therefore the conspiracy was well known. For this reason, Plutarch did not consider it important to define his terms further. This approach, wherein Plutarch assumes certain prior knowledge of the readers, can be found in other parts of De garrulitate, as well as in his other works. ${ }^{3}$ Therefore, we will regard the passage in the essay as another source on the Pisonian conspiracy. ${ }^{4}$

I will introduce the two versions, Plutarch's and Tacitus', in order to distinguish between them, as well as to allow a better understanding of the present text. Tacitus writes:

Sed mirum quam inter diversi generis ordinis, aetatis sexus, ditis pauperes taciturnitate omnia cohibita sint, donec proditio coepit e domo Scaevini; qui pridie insidiarum multo sermone cum Antonio Natale, dein regressus domum testamentum obsignavit, promptum vagina pugionem, de quo supra rettuli, vetustate obtusum increpans asperari saxo et in mucronem ardescere iussit eamque curam liberto Milicho mandavit. simul adfluentius solito convivium initum, servorum carissimi libertate et alii pecunia donati; atque ipse maestus et magnae cogitationis manifestus erat, quamvis laetitiam vagis sermonibus simularet. postremo vulneribus ligamenta quibusque sistitur sanguis parare eundem Milichum monet, sive gnarum coniurationis et illuc usque fidum, seu nescium et tunc primum arreptis suspicionibus, ut plerique tradidere de consequentibus. nam cum secum servilis animus praemia perfidiae reputavit simulque

\footnotetext{
${ }^{2}$ Suet. Ner. 36.

${ }^{3}$ For example, in the essay De garrulitate, Plutarch presumes Anacharsis is a protagonist already familiar to readers, and that he does not need to introduce the character further (Plut. Mor. 504f-505a). The assumption that Anacharsis is a famous personality is supported by the fact that various ancient authors mention him: Hdt. IV 76-77; Cic. Tusc. Disp. V 32; Athen. IV 159, X 428, 437, XIV 613; Ael. VH. V 7; Diog. Laert. I 101-105. To illustrate the point further, Plutarch also mentions Harmodius and Aristogeiton, stating only that they were members of the conspiracy (Plut. Mor. 505e-f). Every Greek knew their names, as well as their stories (Thuc. VI 54-59; Arist. Ath. Pol. XVIII 2). An example from the biographies was also shown by Pelling, C.: De Malignitate Plutarchi. Plutarch, Herodotus and the Persian Wars. In Cultural Responses to the Persian Wars. Ed. E. BRIDGES - E. HALL - P. J. RHODES. Oxford 2007, 153

4 Plutarch's report was also connected to the Pisonian conspiracy by SHERK, R.: Translated Documents of Greece\&Rome. Cambridge 1988, 70. V. E. PAGÁN also treats Plutarch's passage as a version of the Pisonian conspiracy (Conspiracy Narratives in Roman History. Austin 2004, 83-84).
} 
immensa pecunia et potentia obversabantur, cessit fas et salus patroni et acceptae libertatis memoria. ${ }^{5}$

On the other hand, Plutarch stated the following reason:

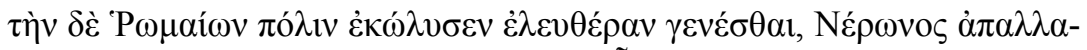

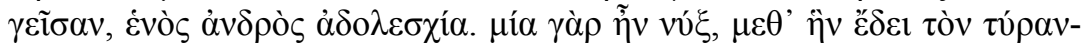

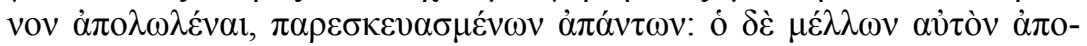

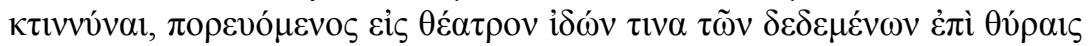

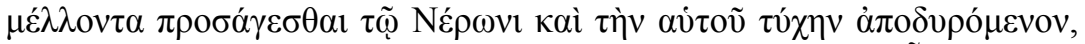

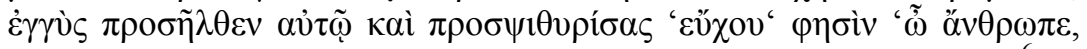

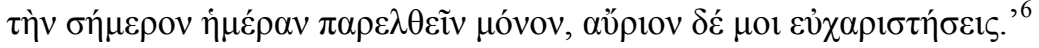

Plutarch was apparently familiar with a different version than was Tacitus. Across Rome, there were multiple versions of various aspects of the Pisonian conspiracy both oral and written. In fact, Tacitus himself points to different versions of the story three times in his analysis. ${ }^{7}$ Despite this, historians rely almost exclusively on Tacitus' version of events, while avoiding Plutarch's. However, looking at the text of $\mathrm{An}$ nales alone, it is apparent that Tacitus' main resources addressed the suppression of the conspiracy. ${ }^{8}$ The plot's beginnings ${ }^{9}$ and members,${ }^{10}$ as well as the latters' exact motives ${ }^{11}$ and mutual interconnection, ${ }^{12}$ were mostly unknown to him. For that reason, Plutarch's writings can be considered relevant, even though he delivered his version in the Moralia rather than in a historical work. Despite this, to my knowledge, Plutarch's text has not been researched thoroughly in a historical context. Therefore, this paper will focus on assessing the relevance of Plutarch's story, his relation to Tacitus, and how his report fits into the framework of the conspiracy theory as laid out in the work of Tacitus. Plutarch's version will be methodologically analyzed and evaluated in three points:

${ }^{5}$ Tac. Ann. XV 54.

${ }^{6}$ Plut. Mor. $505 \mathrm{c}-\mathrm{d}$.

${ }^{7}$ Tacitus first mentions the different versions during his analysis of Piso's potential rivals for the throne (Ann. XV 52). Secondly, he refers to different versions when discussing the origin of Scaevinus' dagger, which was to be used in the murder of Nero (Ann. XV 53). Thirdly, we see he has to deal with two versions when discussing Milichus' part in the conspiracy (Ann. XV 54).

${ }^{8}$ Tacitus drew from the senate registers to describe subsequent events (Ann. XV 74); thus, his analysis can be considered reliable. Although it does discuss the accuracy with which Tacitus connected the transcripts, the latest research, which compares the discovered transcripts with Tacitus' texts, confirms that Tacitus really knew the content of some of the transcripts, although he approached them from his own perspective. See BARRETT, A. - YARDLEY, J.: Tacitus. The Annals. Oxford 2008, xxii-xxiii. To understand Tacitus' perspective, see also American Journal of Philology 120/1 (1999), which focuses on Tacitus and his perception of senate acts. Besides the transcripts, he identifies his other source as Fabius Rusticus (Ann. XV 61).

${ }^{9}$ Tac. Ann. XV 49.

${ }^{10}$ Tac. Ann. XV 51.

${ }^{11}$ Tacitus explained the specific reasons which motivated the members to conspire only in the cases of Lucan, Afranius Quintianus, and Faenius Rufus. With regard to Faenius Rufus, Tacitus was outright surprised at his participation (Ann. XV 49-50).

${ }^{12}$ Tac. Ann. XV 54. 
(1) An analysis of the literary and historical elements of Plutarch's essay. The essay De garrulitate was written with an apparent moral goal, and historical events were used to illustrate the claims. Thus, the question arises as to whether Plutarch changed the stories to fit his arguments. If so, in what way did he do so? Answering this question is key to determining the historical relevance of individual elements of the passage.

(2) An assessment of Plutarch's and Tacitus' sources. Their two versions differ, which raises the question as to whether the authors drew from different sources, or whether the disparity is a result of their own selectiveness. For instance, if Plutarch was familiar with Tacitus' version, his own can be identified as a selection or modification, as mentioned in point (1), prompted by the character of the essay; this also demonstrates the relevance of Plutarch's version.

(3) Framing the message into context. Based on the evaluation of the previous two points, we will attempt to connect the elements of Plutarch's version into the existing framework of events which were concomitant with the conspiracy.

\section{LITERARY AND HISTORICAL ELEMENTS}

Plutarch wrote his essay De garrulitate with a clear moral goal. He warns his readers that, through excessive talkativeness, one can lose the interest of listeners, as well as one's own credibility. He compares the trait to drinking too much wine, and claims that the former is even worse than the latter. ${ }^{13} \mathrm{He}$ presented the destructive consequences of talkativeness, as well as heroic examples of silence, using a large number of stories from both history and mythology. ${ }^{14}$ The list of examples was concluded with an assessment of talkativeness as a disorder; this was followed by an extensive discussion of how to treat it. ${ }^{15}$

Thus, the essay is mainly moralistic, rather than historical. Stories from history are used to support the arguments - to confirm Plutarch's moral conclusions. Therefore, the stories may have been altered. There is, however, no direct way of determining whether Plutarch had modified the passage about the conspiracy in the same way, because there are no texts available for comparison. Plutarch's version is unique in ancient literature, and this is the only time Plutarch mentions it in all of his works. Fortunately, Plutarch used various other stories in his essay De garrulitate, some of which also appear in his biographical work Vitae parallelae; therefore, through a comparative analysis, we can scrutinize his work with a firm knowledge of the historical elements used in the Moralia.

\footnotetext{
${ }^{13} 502 \mathrm{e}-504 \mathrm{e}$.

$14504 \mathrm{e}-510 \mathrm{c}$.

${ }^{15} 510 \mathrm{c}-514 \mathrm{f}$.
} 
There are numerous examples of such elements throughout De garrulitate, as well as in "Lives", 16 but they are truly represented by an allusion to Sulla's conquest of Athens. ${ }^{17}$ In this comparison we presuppose several premises. Firstly, we assume that the differences between the biography and the essay are not the result of Plutarch acquiring new information. A contextual comparison shows that when Plutarch was writing Sulla's biography, he had available the same information as when he was writing De garrulitate. Given that the moralistic essay was one of Plutarch's final writings, ${ }^{18}$ we can conclude that he used the same sources as with Vitae parallelae. Furthermore, we are relying on the thesis that the differences between the works were not a consequence of Plutarch failing to consult the sources, and that neither are they the product of Plutarch writing from memory only. Van de Stockt showed that Plutarch consulted his own texts during the writing of Moralia. ${ }^{19}$ In addition, the Greek author sometimes used his moralistic essays during the writing of the biographies, ${ }^{20}$ which indicates that he did not consider the former less reliable.

Thus, we can conclude that the differences between the biographies and the essays are an artifact of Plutarch's concerted efforts to lead each of his works in a different direction; in Vitae parallelae, he strives for objectivity when describing the historical events, despite also addressing the moral character of the subjects. ${ }^{21}$ The

\footnotetext{
${ }^{16}$ For example, Plut. Mor. 506c-d and Plut. Dem. 28; Plut. Mor. 506d-e and Plut. Eum. 6-7; Plut. Mor. 508f-509a and Plut. Dio. 7.

${ }^{17} 505 \mathrm{a}-\mathrm{b}$.

${ }^{18}$ The chronological division of the works remains problematic. The study of C. P. JONES (Towards a Chronology of Plutarch's Works. JRS 56 [1966]) has become a ground-breaking work in this field. This author categorized the essay De garrulitate as one of the first of Plutarch's moral essays. Jones (p. 70) premised this assertion on the fact that the essay was written relatively shortly after the events took place. However, he did not consider that Plutarch also mentions Eumenes, who convinced his soldiers to remain in his army using an artifice $(506 \mathrm{~d}-\mathrm{e})$. This is information that Plutarch only acquired after having worked on Eumenes' biography, which is one of his latest works. More on that can be found in NikOLAIDIS, A.: Plutarch's Methods: His Cross-references and the Sequence of Parallel Lives. In Historical and Biographical Values of Plutarch's Works. Studies Devoted to Professor Philip A. Stadter by the International Plutarch Society. Ed. A. P. JIMÉNEZ - F. TITCHENER. Málaga 2005, 316; NiKOLAIDIS, A.: Plutarch's Heroes in the Moralia: a Matter of Variatio or Another (More Genuine) Outlook? In The Unity of Plutarch's Work: 'Moralia' Themes in the 'Lives', Features of the 'Lives' in the 'Moralia'. Ed. A. NIKOLAIDIS. Berlin - New York 2008, 230. The latest research shows that the essay needs to be considered as having a much later date. It tends to be counted among the works which Plutarch wrote during Trajan's age. See DumORTIER, J.: Plutarque. Paris 1975, 224; PetTine, E.: Plutarco La loquacitá. Napoli 1992, 28-29; NIKOLAIDIS: Plutarch's Heroes 230. We could add that Sulla's biography and De garrulitate may have been created at the same time, because Sulla's biography also belongs among his latter works (NIKOLAIDIS: Plutarch's Methods 307-309); we know that Plutarch worked on biographical and moralistic writings simultaneously. See GeIGER, J.: Lives and Moralia: How Were Put Asunder What Plutarch Hath Joined Together. In The Unity of Plutarch's Work 5.

${ }^{19} \mathrm{He}$ shows it for example in De tranquillitate animi and De adulatore et amico. See VAN DER STOCKT, L.: A Plutarchan Hypomnema on Self-Love. AJPh 120 (2008) 596.

${ }^{20}$ SANCHÉZ, A. V.: Plutarco Compositor de Vitae y Moralia: análisis intratextual. In The Unity of Plutarch's Work (n. 18) 214-215.

${ }^{21}$ Plutarch points to this effort quite clearly in Cimon's biography: ...

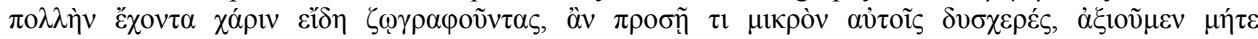

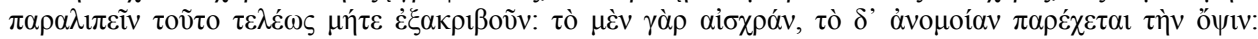

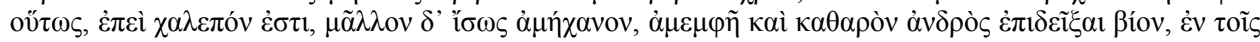


contrast in the contexts of the two works leads to a different understanding of some of the facts presented in "Lives" and Moralia.

A. Nikolaidis performed a broad-reach comparison of Vitae parallelae and Moralia, and attempted to capture Plutarch's approach in these forms; he concluded that

"When the treatment of a character or the account of an event in the Moralia is different from the respective treatment or account in the Lives, this difference sometimes betrays Plutarch's genuine and settled beliefs on the matter concerned, and sometimes is due to adaptations of his material, so as to serve the context or the objectives of the essay at hand."22

Let us now compare the respective passages in the biography of Sulla and De garrulitate. In his text about Sulla, Plutarch records that the former was besieging Athens with his armies, and that he needed to conquer the city in the shortest possible time, as he was facing obstacles elsewhere in the Mediterranean (problems with Mithridates in Asia Minor, and with the party of Gaius Marius in Rome). It was talkativeness which helped Sulla defeat the city, and which brought destruction upon the Athenians. Sulla's spies listened to the old men at the barbers' shop talking about the city's defenses, pointing out that part of the city wall at the Heptachalcum had been neglected. The spies informed Sulla, who was then able to quickly conquer the city.

Thus, not only was the story preserved in the essay, but it was mentioned in Plutarch's biography of Sulla. ${ }^{23}$ When comparing the various elements of both sources, we focus here on the differences in context and development. The story develops in the same context: Sulla needs to conquer Athens quickly; however, the versions differ in the details. In the essay, the reason Sulla was pressed for time during the siege was that he was in danger from Mithridates, as well as from Gaius Marius; by contrast, in the biography, Sulla is merely worried about a possible insurgency, and the reason behind the time constraint is the unmanageable expense of the siege. In the essay, in keeping with the apparent a priori purpose of the story, the report of the historical event finishes with a moral: Sulla defeated Athens not because of the actions of the citizens, but because of their words. Plutarch mentioned this motif in the biography only as a second possible cause, and he did not deal with it at such length as in the essay. ${ }^{24}$ These differences point out to how Plutarch works with his information in Moralia. The main framework of the story stays intact, but the context of a moralistic lesson brings forward a different rendering of the details. Let us now apply these observations to the passage on the Pisonian conspiracy.

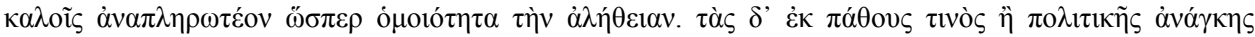

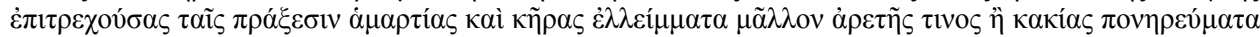

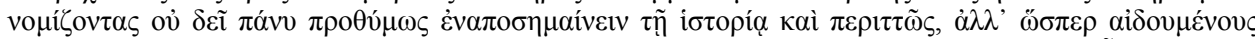

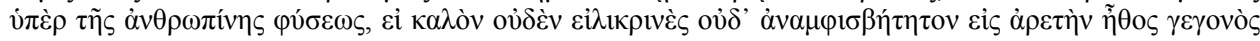

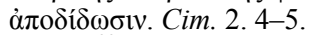

${ }^{22}$ NIKOLAIDIS: Plutarch's Heroes (n. 18) 230.

${ }^{23}$ Plut. Sull. 14.

${ }^{24}$ Athenians mocked Sulla for his skin: "Sulla has a face like a mulberry sprinkled with flour." We can also find this information in the biography, but in a completely different context. Plut. Sull. 2.
} 
Based on the above analysis, it can be assumed that Plutarch did not change the context of the story, and that he remained truthful to what he had heard or read. Thus, the story was one of many that were circulating regarding the Pisonian conspiracy. An issue therefore arises as to its accuracy - as shown in the comparative analysis above, Plutarch did not place such large importance on the details in Moralia as in $\mathrm{Vi}$ tae parallelae. The topic of the work, a criticism of talkativeness, constitutes a sequence of thoughts; for this reason, the information concerning the time (the day before the conspiracy) or the protagonist (the man who was to kill $\mathrm{Nero}^{25}$ ) were not as important in De garrulitate. That is, Plutarch's work with these details was limited by literary continuity more than objectivity. Plutarch's claim that the talkativeness of the protagonist was the main reason for the failure of the conspiracy is another issue with the text. The possibility cannot be excluded that Plutarch was familiar with other versions of the event. In any case, the only reason the Pisonian conspiracy appeared in Moralia is that it gave Plutarch an opportunity to emphasize a particular human characteristic - talkativeness. Regardless of whether or not Plutarch was familiar with other versions, the intent of De garrulitate only allowed for this one. Similarly, in the story of Sulla and the siege of Athens, the explanation of the conquest relies solely on one factor: the talk of the citizens. In conclusion, from a literary-historical point of view, Plutarch's claims in Moralia concerning the story of the conspiracy remain only relative.

\section{PLUTARCH'S SOURCES}

With regard to the differences between Plutarch's and Tacitus' versions, the question remains as to whether this can be connected to their use of different sources, or rather their selectiveness. Answering this question could help demonstrate the relevance of Plutarch's passage - if we assume he knew both versions, we gain another piece of evidence for the above statement: the version Plutarch used in Moralia is not the only one he knew, and he only used it as part of a thematic selective process.

Plutarch's biography on Nero has not been preserved, making it unclear whether Plutarch was familiar with the version Tacitus puts forward. Nonetheless, it is probable, because he had access to the sources. In this regard, let us mention a few basic facts. Plutarch was a contemporary of the Pisonian conspiracy; in the year 68, he attended the games in Delphi while Nero was there. ${ }^{26}$ During his lifetime he gained many Roman friends and visited Rome multiple times. ${ }^{27}$ The information he acquired

\footnotetext{
${ }^{25}$ Based on Tacitus (Ann. XV 50), W. C. Helmbold rather daringly suggests that Plutarch's protagonist may be Subrius Flavus. See Helmbold, W. C. (trans.): Plutarch's Moralia. London 1976, 414. However, definitively identifying Plutarch's man is impossible based on the existing sources, and Tacitus never mentions Subrius Flavus in the context of the discovery of the conspiracy, leaving Hembold's suggestion quite improbable.

${ }_{26}$ Plut. Mor. 385b.

${ }^{27}$ Some of Plutarch's Roman friends are mentioned in his essay "Table Talk". See also JONES, C.: Plutarch and Rome. Oxford 1971, 39-64.
} 
through oral tradition served as an important source for the history of the time. ${ }^{28}$ Finally, he could draw from the Roman authors. Although Plutarch started learning Latin later in life, and he never reached a level comparable to that of his native tongue, ${ }^{29}$ it can be shown that he spoke Latin fluently and was able to read it without any obstacles; indeed, he used many Roman authors as sources, mainly when writing Vitae parallelae. $^{30}$

Although Nero's biography has not survived, Plutarch's other biographies - particularly those of Otho and Galba - show us that he used various sources when reporting historical events, some of which were identical with what Tacitus used in Historiae. ${ }^{31}$ Based on the research so far, we can exclude Tacitus as one of Plutarch's sources, ${ }^{32}$ and vice versa. ${ }^{33}$

Therefore, we can conclude that Plutarch and Tacitus relied on similar sources for their texts; we can also assume that this is true of Plutarch's biography of Nero. There are several mutual sources; namely Cluvius Rufus ${ }^{34}$ and Pliny the Elder, ${ }^{35}$ as well as another possible author, ${ }^{36}$ unknown to this day. In the case of the Pisonian conspiracy, Tacitus explicitly specifies Pliny as one of his sources, ${ }^{37}$ but he may also have been drawing from Fabius Rusticus, ${ }^{38}$ as well as from other, unidentifiable

${ }^{28}$ We know that Plutarch knew eyewitnesses, such as Mestrius Florus (Oth. 14), whom he consulted when writing the contemporary history. However, Plutarch repeatedly uses oral tradition when interpreting older history. For example, Plut. Sull. 14, or even in the essay De garrulitate, where he mentions the story of Leaine ( $505 \mathrm{~d}-\mathrm{e})$; therein, Pausanias claims that he never read the story, but that Athenians are very familiar with it (I 23).

${ }^{29}$ Plut. Dem. 2.

${ }^{30}$ Schettino, M.: The Use of Historical Sources. In A Companion to Plutarch. Ed. M. BECK. Oxford 2014, 423-424.

${ }^{31}$ For more on the mutual sources of Tacitus' first book of Historiae and Plutarch's Vitae parallelae, see Fuhrman, M.: Das Vierkaiserjahr bei Tacitus. Philologus 104 (1960) 264-269. Plutarch only mentions by name Marcus Cluvius Rufus (Oth. 2) and Julius Secundus (Oth. 9). Regarding the latter, we can presume that Plutarch only used him when writing Otho's biography, not as a source for Nero's biography. For a comparison of sources used by Plutarch in the biographies of Otho and Galba to those used by Tacitus, see DE BLOIS, L.: Plutarch's Galba and Otho. In A Companion to Plutarch (n. 30) 272-275; SCHETTino (n. 30) 433-435.

${ }^{32}$ Considering that Plutarch's Vitae parallelae preceded Tacitus' Historiae, the Greek could not have drawn on them. See MARTIN, R.: Tacitus. London-Berkeley 1981, 190; ASH, R. - WELLESLEY, K. (trans.): Tacitus. The Histories. London 2009, xxix. Many authors have rejected the idea that Plutarch used Tacitus as a source, based on the inside analysis and comparison of the texts; SYME, R.: Tacitus. Oxford 1958, 674; SAGE, M.: Tacitus' Historical Works. ANRW 33.2. Berlin - New York 1990, 894. Others hold a contrasting view; for example, RAOSS, M.: La rivolta di Vindice ed i sucesso di Galba. Epigraphica 22 (1960) 46-122.

${ }^{33}$ There can of course be no definitive proof that Tacitus never sourced from Plutarch substantially; however, there are some indicators. Firstly, there is no mention of Plutarch in his works. Secondly, as a man living in Italy, Tacitus had an abundance of local sources, and did not need to extend his research to the Greek author. Lastly, he wrote a different type of work from Plutarch.

${ }^{34}$ In contrast, see TowSAND, G.: The Sources of the Greek in Suetonius. Hermes 80 (1960) 107.

${ }^{35}$ Tacitus quotes Pliny's work Bella Germaniae (Ann. I 69); further, TowsAND, G.: Some Rhetorical Battle-Pictures in Dio. Hermes 92 (1964), 470-471; SAGE (n. 32) 893-897.

${ }^{36}$ Georgiadou, A.: The Lives of Caesars. In A Companion to Plutarch (n. 30) 254.

${ }^{37}$ Tac. Ann. XV 53.

${ }^{38}$ Tac. Ann. XV 61. 
authors, ${ }^{39}$ including the registers of the Roman senate (commentarii senatus). Tacitus was familiar with the content of some of these records, and even mentions them once in connection to the Pisonian conspiracy. ${ }^{40}$ Drawing on the senate registers, he writes that, after the failure of the conspiracy, it was proposed that a temple to the divine Nero be built at the state's expense. Presumably, this very information about the exaltation of the emperor was the key subject of the official record. Tacitus did not know about the events in Scaevinus' house, which led to the discovery of the conspiracy (XV 54), from Senate acts; indeed, he specifically claims that many authors have noted it. ${ }^{41}$ Thus, there is no reason to presume that Plutarch did not know about the same events. Moreover, both authors used information acquired from hearsay when necessary; ${ }^{42}$ we cannot exclude the possibility that each attained their version using this method in the present case. Nonetheless, it seems improbable, considering the importance of the conspiracy concerned. Even though there were many different versions of the events, we can presume that they were all widespread throughout Rome in the years following the Pisonian conspiracy. ${ }^{43}$ Given the interesting narrative point, this should be expected, especially with the extant versions.

Based on the aforementioned assumptions, it appears that the differences between Plutarch's and Tacitus' versions are not due to their different sources, but rather that they may be due to selectiveness by both authors.

\section{CONTEXTUALIZATION}

It follows from the above text that Plutarch was indeed familiar with Tacitus' version of the discovery of the Pisonian conspiracy, ${ }^{44}$ but that the intent of the essay De garrulitate led him to emphasize a different version in which the main reason for the discovery was talkativeness. However, the main culprit was not talkativeness, as revealed when Plutarch admits that the tortured man revealed nothing, and that the man's testimony cannot therefore be considered essential to the discovery of the broad network of perpetrators. In addition, we know that he was not the only person interrogated; some time before him, a different member of the conspiracy - a woman named Epicharis - was also questioned. ${ }^{45}$ Nevertheless, Plutarch's text is significant to our understanding the context of the conspiracy; it indicates the size to which the conspiracy grew. It was not limited to a handful of people, but rather grew to such large proportions that even the members themselves no longer knew everyone who was partaking. This is documented in the aforementioned note from Tacitus regard-

${ }^{39}$ Tacitus himself mentions other sources, but does not specify any names in the passage Ann. XV 54.

${ }^{40}$ See n. 8.

${ }^{41}$ Tac. Ann. XV 54.

${ }^{42}$ Tacitus cites oral tradition twice in the Annales: Ann. III 16; XI 27. For more on Plutarch, see n. 28.

${ }^{43}$ Tacitus himself mentions three times the spreading of various versions of the conspiracy: Tac. Ann. XV 52, 53, 54.

${ }^{44}$ Plutarch's behavior in this instance was not in any way unique; he states different versions more than once in his biographies. For example, Plut. Alc. 13; Nic. 11.

${ }^{45}$ Tac. Ann. XV 51. 
ing Epicharis, wherein she tried to persuade the captains of the fleet in Misenum to participate in the conspiracy. However, not even Tacitus knew how Epicharis originally gained knowledge of the plot. We find the Roman historian in a similar situation to that of the man who was to murder Nero - Scaevinus. Tacitus lacked knowledge as to whether the freedman Milichus had learned about the conspiracy on the fateful day, or rather had known about it for some time. Considering the honesty of the members, it was difficult to keep the conspiracy a secret; we should consider Plutarch's message in this context. The protagonist of the conspiracy, just one among the plot's many members, shared his information further. This slip of the tongue was not in itself the reason for the discovery of the conspiracy, but it certainly added to it. In this period, there were probably multitudes of indications regarding conspiracies at Nero's court. The stories of Epicharis and Plutarch's protagonist were certainly not the only ones, and once Scaevinus' freedman appeared, the emperor's administration began a thorough investigation. In this context, it seems that Plutarch's version does not contradict Tacitus' note, but rather that it can be considered complementary. There are no definitive answers, considering the lack of sources; thus, all arguments above remain hypothetical.

Michal Habaj, PhD

University of SS. Cyril and Methodius

Nám. J. Herdu č. 2.

91701 Trnava

Slovakia

michal.habaj33@gmail.com 